KA N D A I

\begin{tabular}{|l|l|l|}
\hline Volume 16 & No. 1, Mei 2020 & Halaman 13-26 \\
\hline
\end{tabular}

\title{
IKLAN POLITIK DALAM PEMILIHAN KEPALA DAERAH BALI 2018: KAJIAN SEMIOTIKA \\ (Political Advertisement of Bali Election: Semiotic Study)
}

\author{
Sang Ayu Putu Eny Parwati \\ Balai Bahasa Bali \\ Jalan Trengguli I No. 34, Tembau, Denpasar, Indonesia \\ Telepon (0361) 641714, Faksimile (0361) 463656 \\ Pos-el: ayuparwati@hotmail.com
}

(Diterima: 7 Mei 2019; Direvisi: 30 Januari 2020; Disetujui: 16 April 2020)

\begin{abstract}
The use of language in the political realm as a means of campaigning aims to promote political figures. The language of political advertising usually contains expressions in the form of imperative and declarative sentences. In addition, political advertising also displays nonverbal signs that contain myths that develop in society. This study revealed the problem of the meaning of the sign in the 2018 Bali regional election political advertising through the study of Roland Barthes's semiotics. The aim to be achieved in this research is to describe the meaning of verbal and nonverbal signs in political advertisements explicitly in the 2018 Bali regional election. The method used is the referral method supported by recording and recording techniques. This study found that the verbal signs and conventions displayed in the 2018 regional election advertisement written by various elements of society, both as supporters of the candidate pairs and formal institutions in Bali in general have almost the same meaning, namely from the sociocultural and socioreligious Balinese community in general, such as the use of BS, BJK, and Balinese script which is essentially the hope to be achieved is Balinese peace and harmony in general. On the other hand, the meaning of nonverbal signs in the form of illustrations, logos, colors, and characters who have the power of their respective meanings are based on myths that are still believed by the Balinese to this day, such as the tradition of Pengerebongan, white, red, and black as color symbolization in Trimurti, as well as national hero figures.
\end{abstract}

Keywords: politic advertisement, mean, myth, semiotic

\begin{abstract}
Abstrak
Penggunaan bahasa pada ranah politik sebagai sarana kampanye bertujuan untuk mempromosikan tokoh politik. Bahasa iklan politik biasanya berisi ungkapan dalam bentuk kalimat imperatif dan deklaratif. Selain itu, iklan politik juga menampilkan tanda-tanda nonverbal yang mengandung mitos yang berkembang di dalam masyarakat. Penelitian ini mengungkap masalah makna tanda pada iklan politik Pilkada Bali 2018 melalui kajian semiotika Ronald Barthes. Tujuan yang ingin dicapai dalam penelitian ini adalah mendeskripsikan secara lugas makna tanda verbal dan nonverbal pada iklan politik pada Pilkada Bali 2018. Metode yang digunakan adalah metode simak dengan didukung oleh teknik rekam dan catat. Kajian ini menemukan bahwa pesan tanda verbal dan konvensikonvensi yang ditampilkan pada iklan pilkada 2018 yang ditulis oleh berbagai elemen masyarakat, baik sebagai pendukung pasangan calon maupun lembaga formal di Bali pada umumnya memiliki makna yang hampir sama, yakni bertolak dari sosiokultural dan sosioreligius masyarakat Bali pada umumnya, seperti penggunaan BS, BJK, dan aksara Bali yang pada intinya harapan yang ingin dicapai adalah kedamaian dan keharmonisan Bali pada umumnya. Pada sisi yang lain, makna tanda nonverbal dalam bentuk ilustrasi, logo, warna, dan tokoh yang memiliki kekuatan makna masing-masing yang bersumber pada mitos yang masih dipercaya oleh masyarakat Bali hingga saat ini, seperti tradisi
\end{abstract}


Pengerebongan, warna putih, merah, dan hitam sebagai perlambangan warna dalam

Trimurti, serta tokoh pahlawan nasional.

Kata-kata kunci: iklan politik, makna, mitos, semiotik

DOI: $10.26499 / j k . v 16 i 1.1406$

How to cite: Parwati, S.A.P.E. (2020). Iklan politik dalam pemilihan kepala daerah Bali 2018: Kajian semiotika. Kandai, 16(1), 13-26 (DOI: 10.26499/jk.v16i1.1406)

\section{PENDAHULUAN}

Penggunaan bahasa dalam setiap ranah tidak pernah lepas dari tujuan dan fungsi komunikasi yang dilakukan oleh penggunanya untuk menyampaikan pikiran dan perasaan kepada orang lain. Selain itu, bahasa juga memiliki peran penting dalam berbagai ranah, seperti ranah politik, sosial, budaya, hukum, pendidikan, termasuk juga dalam bahasa iklan.

Bahasa iklan memiliki tujuan utama, yakni untuk menarik perhatian pembaca ataupun penyimaknya. Penulis iklan biasanya mengunakan bahasabahasa (kata-kata) khusus yang memiliki makna atau keuntungan tertentu dalam sebuah pernyataan yang tidak lazim dan kontroversial dibandingkan dengan menggunakan bahasa atau kata-kata yang sederhana.

Bahasa iklan dapat berupa bentuk media elektronik dan cetak. Dalam media elektronik, iklan dapat disebarluaskan melalui radio, televisi, internet, dan media elektronik lainnya, sedangkan dalam bentuk cetak, iklan dapat ditemui dalam koran, majalah, berupa brosur, kain rentang (spanduk), dan billboard/baliho. Para penulis iklan bentuk cetak memiliki gaya tersendiri dalam menciptakan bahasanya. Salah satu ciri utama bahasa iklan tersebut adalah persuasif, yakni bersifat membujuk.

Bahasa persuasif biasanya menggunakan bahasa secara halus dalam rangka membujuk dan mengajak masyarakat untuk melakukan sesuatu yang diinginkan oleh pembuat iklan.
Selain itu, ada juga maksud-maksud tertentu di balik wacana iklan yang ingin disampaikan oleh pembuat iklan, baik iklan komersial maupun nonkomersial. Dengan bahasa yang persuasif, tujuan wacana yang dituangkan dalam iklan diharapkan dapat tercapai.

Penelitian ini mengkaji tentang bahasa iklan pemilihan kepala daerah (pilkada) yang tidak dapat dikategorikan ke dalam iklan komersial ataupun iklan layanan masyarakat karena iklan itu tidak menjual produk maupun jasa, tetapi semata-mata meminta dukungan suara dari masyarakat yang ada pada saat menjelang pemilihan kepala daerah dalam kegiatan kampanye. Dengan demikian, iklan pilkada ini dapat dikatakan sebagai iklan politik.

Iklan politik dapat diartikan sebagai semua bentuk ungkapan dalam bahasa verbal dan juga berupa ilustrasiilustrasi dalam bahasa nonverbal untuk memberitahukan dan sekaligus mempromosikan individu maupun partai yang mengusung mereka. Dalam iklan jenis ini, biasanya juga ditampilkan profil calon kandidatnya.

Bahasa verbal yang digunakan dalam iklan politik biasanya berupa susunan kalimat. Berdasarkan bentuk sintaksisnya susunan kalimat dalam iklan politik yang ditemukan dalam data berupa kalimat deklaratif dan kalimat imperatif. Kalimat deklaratif umumnya digunakan oleh pembicara atau penulis untuk membuat pernyataan sehingga isinya merupakan berita bagi pendengar atau pembacanya, sedangkan kalimat imperatif yang digunakan berupa kalimat 
imperatif ajakan dan harapan (Alwi, 1998:352-353).

Mulyani, dkk. (dalam Bandana, 2012, hlm. 178-179) menyatakan bahwa kalimat imperatif secara formal ditandai oleh intonasi rendah diakhir tutur penegas, penghalus, kata tugas ajakan, harapan, permohonan, dan larangan. Predikat biasanya berupa verba yang menyatakan perbuatan dan tidak mendapat awalan meng-. Selain itu, dapat diawali dengan kata tolong, coba, mari, silakan, dan biar.

Bentuk dan wacana iklan politik yang ditampilkan dalam iklan cetak, khususnya dalam media luar ruang yang berupa kain rentang dan baliho mengandung tanda-tanda komunikatif, yaitu tanda verbal dan nonverbal. Sobur (2009, hlm. 116) menyatakan bahwa tanda verbal adalah bahasa yang sudah dikenal oleh masyarakat umum, sedangkan tanda nonverbal adalah bentuk dan warna yang disajikan dalam iklan. Disebutkan pula bahwa dalam bahasa tulis, iklan harus memperhatikan tanda-tanda (sign), makna (meaning), dan latar belakang tertentu yang dapat dipahami oleh masyarakat setempat karena tanda-tanda yang dimunculkan dalam sebuah iklan mewakili realitas sosial yang ada dalam masyarakat. Lebih lanjut diungkapkan pula bahwa konteks budaya juga menjadi sebuah acuan dalam penciptaan sebuah iklan sehingga komunikasi dapat dikatakan berhasil.

Penelitian tentang wacana iklan telah banyak dilakukan oleh pemerhati bahasa iklan, di antaranya Pratiwi (2017) yang berjudul "Makna Tanda Verbal dan Nonverbal pada Iklan 'Wafer Tango" dengan sumber data rekaman audiovisual yang menyatakan bahwa iklan wafer Tango ditampilkan dengan menggabungkan penggunaan tanda verbal dan nonverbal dengan pilihan kata dan aktivitas para pelaku yang sangat unik dan mampu menarik perhatian publik. Pada setiap tuturan verbal dinyatakan dengan makna konotasi seperti pada tuturan, “...Tango juga kenalkan bebek dan Blackberry" dan "Astronot dan asongan pun akrab karenanya...", sedangkan tanda nonverbal digambarkan dengan kondisi fisik tokoh yang dilihat dari beberapa pakaian yang dikenakan seperti peci dan topi serta perlengkapan yang dibawanya, seperti ransel, peta, dan kamera yang menandakan asal mereka (lokal dan asing). Selain itu, moda transportasi (delman dan mobil) yang digunakan pada saat itu menunjukkan bahwa pelaku atau tokoh-tokoh yang sedang berwisata dan sedang menikmati wafer Tango. Kondisi tersebut menandakan bahwa orang kota dan orang desa menyukai wafer Tango. Pada data nonverbal yang lain menandakan bahwa Tango disukai oleh semua kalangan dan dapat mempersatukan si kaya dan si miskin. Tanda lain juga menunjukkan bahwa Tango juga disukai oleh orang tua dan muda (semua generasi). Hasil penelitian ini sangat terbatas, hanya menampilkan makna umum yang dapat dilihat sekejap mata. Jika ditilik lebih mendalam pasti akan menemukan makna lain yang ada pada iklan tersebut.

Sementara itu, Asrofah (2014) yang berpijak pada semiotik mitos Roland Barthes mengungkap tentang beberapa iklan yang menjadi perhatiannya di media massa, baik cetak maupun elektronik, seperti iklan mobil, iklan salah satu penyedia layanan internet (Im3), dan iklan sepeda motor (Honda dan Yamaha). Dalam tulisannya, penulis menyatakan bahwa tanda-tanda dan konvensi-konvensi yang ada pada setiap iklan-iklan tersebut memiliki arti/mengandung arti yang tidak hanya terbatas pada tanda yang berwujud benda saja, tetapi lebih dari itu. Tanda-tanda lain yang dimaksudkan adalah gambar/simbol, warna, logo, merek, 
slogan, dan sebagainya yang mengandung arti bermacam-macam bergantung pada sudut pandang pembaca atau penikmatnya. Disebutkan pula bahwa dalam upaya menciptakan karakter suatu produk, para kreator iklan membuat sistem signifikansi, seperti memberi nama merek, membuat simbol visual, narasi, dan penciptaan sebuah logo ketika sebuah produk diberi nama maka produk tersebut bisa dikenali. Penelitian ini hanya terbatas pada sebuah iklan yang mewakili iklan elektronik dan iklan cetak dan hanya mengungkap signifikansi yang ada pada iklan-iklan tersebut. Sementara itu, kajian tentang mitos tidak terungkap pada penelitian ini.

Penelitian yang terkait dengan iklan politik di antaranya dilakukan oleh Zakiyah (2015) dengan judul "Implikatur dalam Wacana Kampanye Politik Pilkada Calon Gubernur dan Calon Wakil Gubernur Provinsi Lampung Periode 2014-2019" hanya mengungkap tindak tutur dan implikasi yang dominan dalam setiap kampanye politik. Namun, Handono (2017) dalam penelitian yang berjudul "Implikatur Kampanye Politik dalam Kain Rentang di Ruang Publik" sangat jelas mengungkap jenis dan sumber implikasi dalam iklan sebagai sumber datanya. Pada iklan politik tersebut ditemukan tuturan yang mengandung implikasi konvensional dan konversasional. Implikasi yang ada pada iklan tersebut adalah meyakinkan, mengajak, meminta, menjanjikan, dan memerintah. Implikasiimplikasi itu bersumber pada penerapan prinsip kerja sama dan prinsip kesantunan dalam percakapan. Kedua penelitian itu pun tidak mengungkap tentang mitos yang ada pada iklan politik tersebut. Untuk itulah, penelitian ini akan mengupas tentang mitos yang ditemukan dalam iklan Pilkada Bali
2018 dan akan menjadi hal penting dalam penelitian ini.

\section{LANDASAN TEORI}

Ilmu yang mempelajari tentang makna dari tanda-tanda itu adalah semiotik. Konsep semiotika diperkenalkan oleh Ferdinan de Saussure melalui dikotomi sistem tanda: signified dan signifier atau signifie dan significant yang bersifat atomistis. Konsep ini melihat bahwa makna muncul ketika ada hubungan yang bersifat asosiatif atau in absentia antara 'yang ditandai' atau petanda (signified) dan 'sesuatu yang digunakan untuk memberi tanda' atau penanda (signifier), yaitu hubungan yang tidak terpisahkan seperti dua sisi pada koin antara konsep atau makna/yang ditandai dengan imaji suara/penanda. Jadi, ketika salah satu aspek disebut atau ditunjuk maka aspek yang lain akan turut hadir dalam penunjukkan atau penyebutan tersebut. Konsep semion seperti ini oleh de Saussure disebut tanda atau sign.

Hal tersebut dijelaskan oleh Saussure dalam Asrofah (2014, hlm. 2) yang menyatakan bahwa tanda adalah kesatuan dari suatu bentuk penanda (signifier) dengan sebuah ide atau petanda (signified). Dengan kata lain, penanda adalah 'bunyi yang bermakna' atau coretan yang bermakna'. Dengan demikian, penanda adalah aspek material dari bahasa, yaitu apa yang dikatakan atau didengar dan apa yang ditulis atau dibaca, sedangkan petanda adalah gambaran mental, pikiran, atau konsep.

Selain itu, Preminger dalam Asrofah (2014, hlm. 3) mengatakan bahwa semiotik adalah ilmu tentang tanda-tanda yang menganggap bahwa fenomena sosial dalam masyarakat dan kebudayaan itulah yang merupakan tanda-tanda. Semiotik itu mempelajari sistem-sistem, aturan-aturan, dan 
konvensi-konvensi yang memungkinkan tanda-tanda tersebut mempunyai arti.

Ronald Barthes dalam Asrofah (2014, hlm. 3-6) mengungkapkan bahwa semiotik yang diistilahkan dengan semiologi pada dasarnya hendak mempelajari bagaimana humanity (kemanusiaan) memaknai things (halhal), baik secara denotatif maupun konotatif. Hal ini tampak pada bagaimana masyarakat Hindu di Bali pada khususnya menggunakan bahasa dan memaknai tanda yang dikaitkan dengan budaya. Dalam hal ini religi. Selain itu, Barthes juga menyebutkan bahwa tanda denotatif terdiri atas penanda dan petanda, tetapi pada saat bersamaan tanda denotatif adalah juga penanda konotatif. Dalam konsep Barthes, tanda konotatif tidak sekadar memiliki makna tambahan, tetapi juga mengandung kedua bagian tanda denotatif yang melandasi keberadaanya. Dengan demikian, bagi Barthes yang ada hanya makna konotasi yang bersifat alamiah. Lebih lanjut Barthes menyebutkan bahwa konotasi identik dengan operasi ideologi yang disebutnya dengan "mitos" dan berfungsi untuk mengungkapkan dan memberikan pembenaran bagi nilai-nilai dominan yang berlaku dalam suatu periode tertentu. Di dalam mitos juga terdapat pola tiga dimensi penanda, petanda, dan tanda.

Sebagai suatu sistem yang unik, mitos dibangun oleh suatu rantai pemaknaan yang telah ada sebelumnya atau dengan kata lain, mitos adalah juga suatu sistem pemaknaan tataran kedua. Di dalam mitos pula, sebuah petanda dapat memiliki beberapa penanda. Produksi mitos dalam teks membantu pembaca untuk menggambarkan situasi sosial budaya, mungkin juga politik yang ada di sekelilingnya. Bagaimanapun mitos juga mempunyai dimensi tambahan yang disebut naturalisasi.
Melalui dimensi tersbut, sistem makna menjadi masuk akal dan diterima apa adanya pada suatu masa dan mungkin tidak untuk masa yang lain.

Berdasarkan paparan tersebut, tulisan ini ingin mengkaji iklan politik berdasarkan semiotik atau semiologi. Iklan politik yang mewarnai media luar ruang yang dapat dijumpai hampir di sepanjang bahu jalan digunakan sebagai sarana kampanye oleh para kandidat. Iklan-iklan politik yang dimaksud dalam penelitian ini adalah iklan yang berupa kain rentang, billboard/baliho yang ditulis oleh kandidat calon gubernur dan wakil gubernur serta para pendukungnya pada Pilkada Bali 2018.

Pada Pilkada Bali 2018 hanya diikuti oleh dua pasang calon gubernur dan wakil gubernur. Kedua pasang calon tersebut diusung oleh partai politik masing-masing dengan bentuk dan wacana iklan yang sangat menarik untuk dikaji karena iklan-iklan tersebut menampilkan bentuk wacana sosiokultural yang merupakan kearifan lokal daerah Bali yang sarat akan tanda dan mitos. Tanda verbal dan nonverbal yang ditampilkan dalam iklan-iklan politik itu diharapkan mampu memersuasi masyarakat untuk memilih salah satu calon kepala daerah Provinsi Bali periode tahun 2018-2023.

Masalah yang dikaji dalam tulisan ini adalah makna tanda iklan politik pada Pilkada Bali 2018 berdasarkan teori semiotika Ronald Barthes. Fokus kajian ini mengulas makna tanda verbal (bahasa) dan nonverbal (tanda atau simbol), termasuk mitos yang ditemukan dalam iklan-iklan politik tersebut. Masalah ini berpijak pada realitas bahwa bahasa dan budaya tidak dapat dipisahkan satu sama lain sebab budaya dicerminkan oleh bahasa, demikian juga sebaliknya. Bahasa merupakan cerminan pikiran manusia yang merupakan bagian dari masyarakat tempat manusia tersebut 
berada. Dengan demikian, bahasa tentu juga merupakan cerminan dari masyarakat dan masyarakat secara otomatis menjadi bagian dari sebuah kebudayaan sehingga bahasa merupakan cermin budaya. Hal tersebut masih sangat tampak kuat ada dalam kehidupan masyarakat Bali hingga saat ini.

Penggunaan bahasa, baik verbal maupun nonverbal dalam wacana iklan politik sebagai sumber data ini adalah sarana komunikasi yang menggunakan tanda-tanda dan mitos yang maknanya dipahami secara konvensional oleh masyarakat Bali khususnya karena bahasa-bahasa tersebut masih erat kaitannya dengan budaya setempat. Dengan demikian, jika konsep tersebut dikaitkan dengan kajian ini maka dapat dikatakan bahwa penanda adalah coretan yang bermakna atau aspek material dari bahasa, yaitu apa yang ditulis atau dibaca, sedangkan petanda adalah gambaran mental, pikiran, atau konsep yang dapat menciptakan mitos yang dianut masyarakat pada saat itu. Dengan demikian, petanda adalah aspek mental dari bahasa.

Sementara itu, sebuah konsep yang juga terkait dengan kajian ini adalah konsep yang dikutip oleh Handono (2017, hlm. 254) bahwa tuturan (wacana) memiliki makna literal dan makna nonliteral. Makna literal yang disebut juga dengan makna alami sesuai dengan makna kata-kata dalam tuturan, sedangkan makna nonliteral atau makna tidak alami merupakan makna yang tersirat dalam tuturan. Misalnya wacana Mohon doa restu memiliki makna literal jika wacana itu dimaksudkan sebagai ekspresi penutur yang meminta doa dan restu kepada mitra tuturnya karena wacana itu memiliki latar dan tujuan tertentu.

\section{METODE PENELITIAN}

Metode merupakan upaya strategis untuk memecahkan masalah yang meliputi penyediaan data, analisis data, dan penyajian hasil analisis data (Sudaryanto, 2015, hlm. 6). Pemerolehan data pada penelitian ini dilakukan sejak awal Februari 2018 dengan mendokumentasikan sejumlah 68 iklan politik yang menampilkan dua pasang calon gubernur dan wakil gubernur di dua lokasi, yaitu di Kota Denpasar dan Kabupaten Badung.

Selanjutnya, data-data tersebut dipilah sesuai kebutuhan analisis penelitian ini dan terkumpul sebanyak 24 foto yang dijadikan sampel penelitian dalam bentuk $m s$ word. Patton (2009, hlm. 81) menyebutkan bahwa pengambilan sampel atas dasar maksud tertentu terletak pada penyeleksian kasus yang kaya informasi sehingga peneliti dapat memiliki pandangan luas terhadap hal-hal penting yang sebenarnya menjadi maksud dalam suatu penelitian.

Hasil analisis penelitian ini disajikan dalam bentuk deskriptif kualitatif melalui penerapan metode simak dan teknik catat terhadap sampel data yang terkumpul tersebut. Mahsun (2005, hlm. 90) menyebutkan bahwa penelitian kualitatif selalu bersifat deskriptif, artinya data yang dianalisis dan hasil analisisnya berbentuk diskripsi fenomena bukan berupa angka-angka atau koefisien tentang hubungan antarvariabel. Berkaitan dengan hal tersebut data yang terkumpul pada penelitian ini difokuskan pada tanda verbal dan nonverbal yang ada pada kain rentang dan baliho Pilkada Bali 2018 yang dianalisis berdasakan pendekatan semiotika mitos Ronald Barthes dengan menggunakan metode padan. 
Sudaryanto (2015, hlm. 15) menyatakan metode padan adalah metode yang alat penentunya berada di luar dan tidak menjadi bagian dari bahasa yang bersangkutan.

\section{PEMBAHASAN}

Makna verbal dan nonverbal yang ditemukan dalam beberapa iklan politik pada kain rentang dan baliho Pilkada Bali 2018 ini sangat beragam dan memiliki berbagai ukuran. Iklan-iklan tersebut sebagian besar berada di bahu jalan utama yang ada di wilayah Kota Denpasar dan beberapa lokasi di Kabupaten Badung. Seperti telah dikatakan bahwa Pilkada Bali 2018 ini diikuti oleh dua pasangan calon yang diusung atau didukung oleh beberapa partai politik dan relawan (ormas). Setiap calon dan pendukungnya menciptakan iklan politik yang unik dan menarik untuk disimak.

\section{Makna Tanda Verbal dan Nonverbal Iklan Politik Pilkada Bali 2018}

Penggunaan bahasa verbal dalam
iklan politik Pilkada Bali 2018
menggambarkan pemakaian bahasa
campuran antara bahasa Sansekerta (BS), bahasa Jawa Kuno (BJK), bahasa Bali (BB), dan bahasa Indonesia (BI). BS merupakan bahasa yang digunakan dalam kitab suci agama Hindu, Weda, dan penyebarannya menggunakan BJK (yang juga sering disebut dengan bahasa Kawi) pada masa keemasan Kerajaan Majapahit. BJK merupakan salah satu rumpun bahasa Austronesia yang diperkirakan berkembang pada abad IXXV Masehi yang digunakan sebagai alat komunikasi pada waktu itu. Selain itu, bahasa tersebut juga dapat ditemukan dalam karya tulis atau teks-teks kakawin, parwa, babad, dan lain-lain. (Erawati, 2012, hlm. 119). Lebih lanjut disebutkan pula bahwa salah satu kedudukan BJK ini adalah sebagai bahasa dokumenter tertua yang memiliki materi terkaya dan nilai yang tidak dapat diabaikan di antara bahasa-bahasa Austronesia lainnya.

Dewasa ini BJK dikatakan telah mati karena sudah tidak ditemukan lagi penuturnya sebagai alat komunikasi. Walaupun demikian, pada kenyataannya beberapa kata/istilah dalam BS dan BJK masih tetap digunakan dalam berbagai aspek kehidupan masyarakat Bali, khususnya dalam sastra, agama, dan budaya. Pada kenyataannya hingga saat ini, kosakata BS dan BJK tersebut dituliskan pula dengan aksara Bali, aksara Swalalita.

Penggunaan

bahasa-bahasa tersebut dalam iklan politik pada Pilkada Bali 2018 tampak menghiasi iklan politik kedua pasangan calon kepala daerah dan mengandung makna tersendiri, yang mencerminkan sosiokultural masyarakat Bali yang mayoritas beragama Hindu dan masih sangat menjunjung tinggi adat dan budaya Bali. Walaupun demikian, masyarakat Bali juga masih tetap menjunjung tinggi bahasa negara, yaitu bahasa Indonesia yang mencerminkan jati diri bangsa masyarakat Bali yang heterogen. Keunikan penggunaan bahasa dalam iklan politik pada Pilkada Bali 2018 dapat dilihat seperti pada data-data berikut ini.

Gambar 1

Data 1 Penelitian

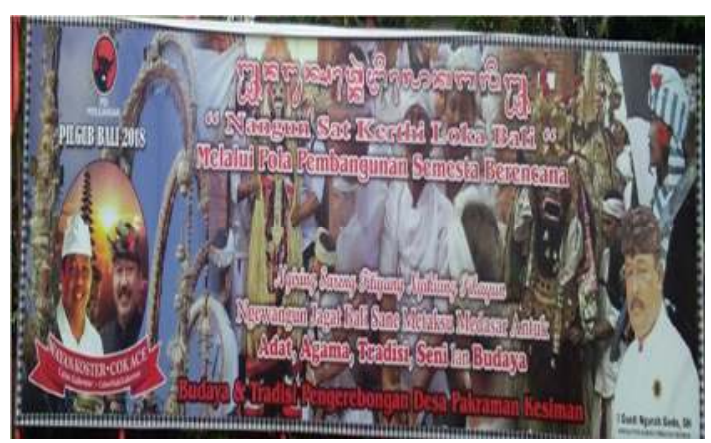


Pada data 1 dapat dilihat, tanda verbal dalam iklan politik yang merupakan visi dari salah satu pasangan calon tersebut menggunakan bahasa campuran. Pada bagian awal digambarkan penulisan aksara Bali yang kemudian dialihaksarakan ke dalam huruf latin yang berbunyi, Nangun Sat Kerthi Loka Bali. Ungkapan tersebut menggunakan BJK dan BS. Jika dijabarkan tiap-tiap kata dalam kalimat tersebut memiliki makna yakni nangun (BJK) 'membangun', sat (BS) 'nyata; kaya', kerthi (BS) 'masyur; nama yang baik', loka (BS) 'adat, dunia, kebiasaan', dan Bali 'nama provinsi'. Secara denotatif ungkapan tersebut mengandung makna 'membangun kemasyhuran alam Bali secara nyata'. Penulis memaknai secara konotatif kalimat tersebut, 'menjaga kesucian dan keharmonisan alam Bali beserta isinya untuk mewujudkan kehidupan dan alam Bali yang sejahtera dan bahagia'.

Selanjutnya, di bawah ungkapan tersebut juga tertulis ungkapan dalam bahasa Indonesia, yakni "Melalui Pola Pembangunan Semesta Berencana". Penulis memaknai ungkapan tersebut bahwa 'melalui pembangunan secara terpola, menyeluruh, terencana, terarah, dan terintegrasi dalam bingkai Negara Kesatuan Republik Indonesia berdasarkan nilai-nilai Pancasila'. Visi tersebut menunjukkan bahwa pasangan calon akan melakukan program kerja yang mengutamakan peningkatan pembangunan di Provinsi Bali yang berlandaskan Pancasila.

Tanda verbal selanjutnya adalah berupa kalimat imperatif dalam BB, Ngiring Sareng Tityang Nyikiang Pikayun Ngewangun Jagat Bali Sane Metaksu Medasar Antuk Adat, Agama, Tradisi, Seni, lan Budaya. Kalimat ajakan tersebut secara denotatif dalam BI bermakna 'mari bersama saya menyatukan asa membangun bumi Bali yang metaksu berdasar pada adat, agama, tradisi, seni, dan budaya'. Kalimat tersebut mengandung makna magis metaksu yang bermakna 'kuat dan suci'.

Petanda metaksu dalam bahasa nonverbal ditunjukkan pada ilustrasi sebuah tradisi pengerebongan yang lengkap dengan ornamen atau simbolsimbol yang ada di setiap upacara besar di Bali, seperti penjor dan warna pakaian yang digunakan oleh masyarakat dalam mengikuti tradisi tersebut. Ilustrasi tradisi pengerebongan tampak pada latar belakang penulisan iklan. Tradisi tersebut merupakan gambaran mental masyarakat di wilayah tersebut yang masih sangat menjunjung tinggi budaya dan tradisi.

Tradisi pengerebongan hanya ada di wilayah Desa Pakraman Kesiman mengandung mitos cerita asal-usul alam semesta di daerah tersebut yang diungkapkan dengan cara-cara gaib. Tampak pula ilustrasi dewa-dewa, Barong Ket dan Rangda, yang merupakan simbol kebaikan dan kebajikan. Simbol-simbol tersebut sebagai penanda mitos yang dipercaya oleh umat Hindu-Bali sebagai penjaga alam semesta beserta isinya dari segala marabahaya.

Selain itu, dapat pula dimaknai bahwa tradisi pengerebongan merupakan upacara sakral bagi masyarakat setempat. Tampak masyarakat dengan antusias mengikuti upacara tersebut dengan berpakaian adat lengkap yang berwarna putih. Warna putih merupakan simbol kesucian dan kekuatan. Dengan menampilkan tradisi itu dalam iklan politik, penulis berharap bahwa pasangan calon pemerintah daerah yang ditampilkan tersebut akan mendukung tradisi dan akan tetap melestarikan tradisi, adat, dan budaya Bali sesuai dengan visi dan misi pasangan calon. Selain itu, juga dapat sebagai sebuah peringatan bahwa Pilkada Bali 2018 
merupakan peristiwa sakral yang wajib diikuti pelaksanaannya oleh seluruh masyarakat Bali dengan memilih pasangan calon yang tampak pada iklan tersebut.

Berdasarkan data 1, dapat diungkapkan bahwa bahasa Bali dalam perkembangannya hingga saat ini banyak menerima pengaruh dari BJK dan BS yang menjadi jati diri masyarakat Hindu. hal itu sebagai penanda bahwa masyarakat Bali masih tetap melestarikan bahasa-bahasa tersebut. Dengan cara demikian, penggunaan bahasa tersebut diasumsikan bahwa penulis ingin membangkitkan kembali pengetahuan masyarakat tentang BJK, BS, BB, dan aksara Bali yang masih ada dan digunakan oleh masyarakat Bali khususnya, walaupun saat ini pemakaiannya tidak secara aktif sebagai alat komunikasi sehari-hari.

BJK, BS, BB, dan aksara Bali yang digunakan secara bersama-sama dapat diamati dan didengarkan dalam berbagai kegiatan ritual keagamaan yang dalam bentuk mantra atau doa suci yang umumnya diucapkan oleh orang suci (pendeta) agama Hindu dan dalam kidung suci yang disertakan dalam setiap upacara keagamaan.

Realitas sosioreligius (mitos) yang ditampilkan dalam iklan politik Pilkada 2018 itu tidak dapat dipisahkan begitu saja dengan bahasa, baik verbal maupun nonverbal sebab bahasa sebagai media bagi manusia untuk merefleksikan rasa religiositasnya dengan berbagai aktivitas keagamaan.

Penggunaan bahasa verbal dalam wacana iklan politik tersebut menandakan bahwa penulis ingin mengupayakan pelestarian penggunaan BJK, BS, BB, dan aksara Bali yang tidak hanya menjadi bahasa sastra dan bahasabahasa seni pertunjukkan, tetapi bahasabahasa itu telah menjadi bahasa ritual yang memiliki nilai magis dan religius yang perlu dipertahankan dan dilestarikan karena bahasa dan agama merupakan bagian dari unsur budaya yang universal.

Selain itu, hal yang mengandung makna sosioreligius dalam umat Hindu di Bali adalah warna. Warna yang disakralkan adalah putih, merah, dan hitam yang merupakan warna lambang trimurti dan mengandung makna tersendiri seperti warna-warna yang digunakan dalam iklan Pilkada Bali 2018. Pada intinya trimurti dalam agama Hindu bermakna tiga perwujudan manisfestasi Ida Shang Widhi Wasa atau Tuhan yang Maha Esa dalam mencipta, memelihara, dan melebur alam semesta beserta isinya.

Berkaitan dengan warna, pada iklan politik pilkada seperti yang tampak pada data 1 yang dapat dikatakan sebagai tanda nonverbal. Warna yang dimaksud tampak pada ilustrasi budaya berpakaian pasangan calon dan pendukungnya serta masyarakat yang mengikuti tradisi pengerebongan. Mereka tampak menggunakan pakaian adat Bali dengan menggunakan destar (ikat kepala), yang khusus digunakan oleh kaum laki-laki di Bali pada saat melaksanakan kegiatan yang berkaitan dengan adat, terutama untuk kegiatan keagamaan.

Warna pakaian masyarakat yang mengikuti ritual itu adalah putih. Seperti telah disebutkan sebelumnya bahwa warna sebagai lambang trimurti, adalah warna putih yang bermakna 'kesucian dan kekuatan' yang merupakan simbol Dewa Siwa.

Data lain yang menggambarkan sosiokultural dan sosioreligius yang dikenal oleh masyarakat Bali adalah seperti pada data berikut. 


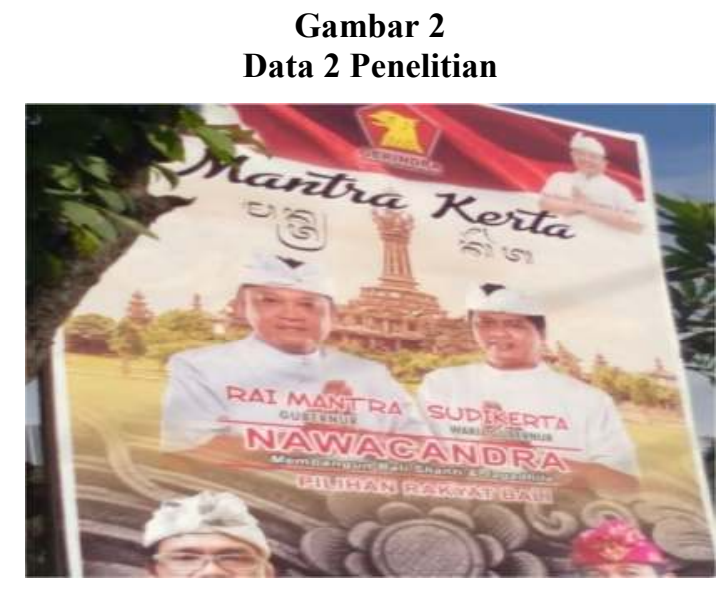

Data 2 tersebut secara verbal juga menggunakan bahasa yang menarik, seperti penggunaan aksara Bali dan bahasa campuran, yaitu BJK, BS, BB, dan BI. Penggunaan huruf tampak pada nama kedua calon, yaitu selain ditulis dengan huruf latin, Mantra Kerta, juga ditulis dengan aksara Bali yang tampak di bagian bawah setelah nama yang bertuliskan dengan huruf latin. Selain itu, tampak pada frasa "Nawacandra" yang berasal dari BS dan sudah diserap menjadi BJK terdiri atas dua kata, yaitu nawa 'sembilan' dan candra 'bulan'.

Kata nawancandra tersebut juga banyak ditemui pada iklan yang menampilkan pasangan calon gubernur dan wakil gubernur tersebut. Tampaknya kata tersebut juga merupakan moto atau semboyan pasangan calon tersebut. Makna denotatif dari nawacandra tersebut adalah bahwa pasangan calon tersebut akan 'membangun pemerataan di sembilan kabupaten dan kota di Bali'.

Selanjutnya, di bawah moto tersebut tertulis visi dalam kalimat deklaratif "Membangun Bali Shanti dan Jagadhita". Visi tersebut menggunakan bahasa campuran BI dan BS (tercetak miring). Kata shanti memiliki makna 'damai' dan kata jagadhita bermakna 'aman'. Penanda verbal dalam kalimat deklaratif tersebut menunjukkan bahwa penulis iklan ingin menonjolkan sosiokultural masyarakat Bali. Visi dari pasangan calon tersebut diiringi dengan frasa dalam bahasa Indonesia "Pilihan Rakyat Bali'. Makna tanda verbal secara denotatif yang terkandung dalam iklan politik tersebut adalah bahwa pasangan calon pemimpin Bali tersebut juga memiliki program yang akan melestarikan adat dan budaya Bali dengan membangun Bali yang damai dan aman jika terpilih nanti.

Sementara itu, penanda nonverbal dan menjadi representament (simbol) atau objek yang ada pada data di atas adalah pasangan calon gubernur dan wakil gubernur dan gambar atau ilustrasi yang menjadi latar belakang dari pasangan calon tersebut. Ilustrasi yang tampak adalah Monumen Bajrasandhi yang merupakan simbol perjuangan rakyat Bali dan menjadi ikon Kota Denpasar, Ibu Kota Provinsi Bali.

Dalam hal ini, penulis menampilkan ikon tersebut sebagai penanda bahwa pasangan calon tersebut merupakan pasangan calon "Pilihan Rakyat Bali" yang pantas untuk memperjuangkan dan melestarikan adat dan budaya Bali. Selain itu, gambar pasangan calon juga ditampilkan dengan berpakaian adat Bali yang berwarna putih (baju dan destar). Warna putih memiliki mitos yang menandakan bahwa warna tersebut melambangkan sesuatu yang bersih dan sebuah kesucian serta diyakini memiliki kekuatan seperti yang telah disebutkan sebelumnya.

Berdasarkan hal tersebut dapat dikatakan bahwa penulis juga ingin menyampaikan jika pasangan calon tersebut adalah orang-orang yang memiliki "kekuatan" dan pantas menjadi pilihan rakyat Bali. Selain itu, iklan tersebut juga dapat dipastikan bahwa penulis iklan adalah seorang pendukung pasangan calon gubernur dan wakil gubernur yang merupakan kader dari salah satu partai politik. Hal tersebut dapat dibuktikan dengan penandanya 
adalah logo salah satu partai politik yang ada di bagian atas iklan.

Gambar 3

Data 3 Penelitian

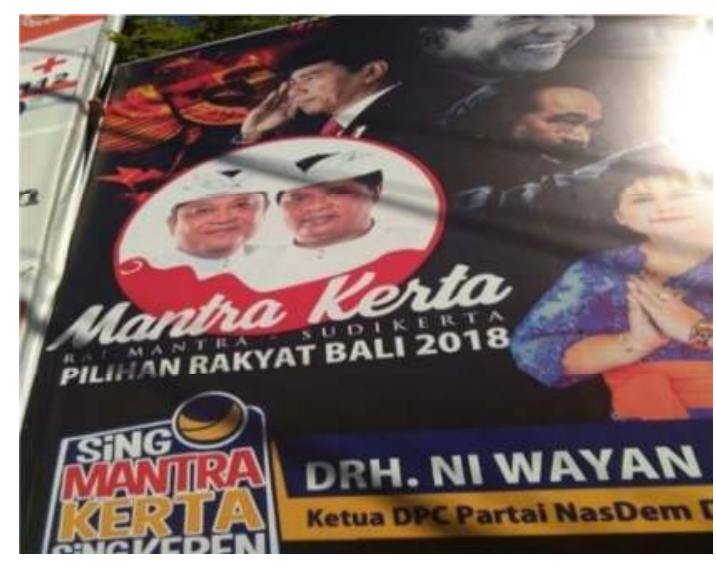

Tanda verbal yang tampak pada data 3 berupa kalimat deklaratif yang umumnya berupa pernyataan sehingga isinya merupakan berita bagi pembacanya. Kalimat deklaratif yang dimaksud adalah "Mantra Kerta Pilihan Rakyat Bali 2018" dan menampilkan ungkapan yang menarik pada iklan ini adalah "Sing Mantra Kerta Sing Keren". Tampak penggunaan bahasa campuran, BB dan BI, yang tak dapat dihindari dalam iklan politik Pilkada Bali 2018.

Petanda BB dalam iklan tersebut adalah kata sing yang dalam BI berarti 'tidak' dan BI pada kata keren 'tampak gagah dan tangkas'. Dalam hal ini, penulis ingin menyampaikan kepada pembaca (masyarakat) bahwa jika tidak memilih Mantra Kerta, tidak keren karena pasangan calon tersebut merupakan "Pilihan Rakyat Bali". Kata keren tersebut dapat bermakna sesuatu yang positif 'tampak gagah dan tangkas'. Dengan demikian, ungkapan tersebut secara denotatif bermakna "jika seseorang (masyarakat) tidak memilih pasangan calon tersebut, orang tersebut tidak tampak gagah dan tangkas dalam Pilkada Bali 2018".

Tanda nonverbal yang tampak pada data 3, selain simbol objek pasangan calon yang ditampilkan pada iklan tersebut juga tampak lambang negara Indonesia yaitu Garuda Pancasila yang memiliki mitos bahwa simbol itulah yang menyatukan seluruh rakyat Indonesia. Selain itu, juga menampilkan tiga orang tokoh yang berpengaruh di Indonesia. Mitosnya, ketiga tokoh tersebut sangat berperan dalam lahirnya negara Indonesia.

Tokoh yang ditampilkan adalah Ir. Soekarno yang merupakan proklamator kemerdekaan Indonesia (pahlawan nasional) dan yang menyatukan seluruh rakyat Indonesia sehingga dilambangkan dengan Garuda Pancasila; Joko Widodo, Presiden Indonesia, yang memimpin negara Indonesia saat itu; dan Surya Paloh sebagai ketua umum salah satu partai yang mendukung pasangan calon yang ditampilkan dalam lambang partai pengusung pasangan calon tersebut.

Selain itu, tampak juga warna dasar iklan adalah hitam. Dalam ajaran trimurti yang dilambangakan dengan tiga warna yang sakral bagi umat Hindu, warna hitam melambangkan kemurnian, kesucian, dan kesederhanaan. Dalam trimurti, juga disebutkan warna hitam merupakan simbol Dewa Wisnu

Dengan kolaborasi antara tanda verbal dan nonverbal dalam iklan politik tersebut dapat dimaknai bahwa penulis yang merupakan kader partai pendukung pasangan calon ingin menyampaikan bahwa pasangan calon tersebut merupakan pilihan masyarakat Bali pada Pilkada Bali 2018 yang merupakan penerus ketiga tokoh nasional yang memiliki "kekuatan" dalam menyatukan seluruh rakyat Indonesia. 


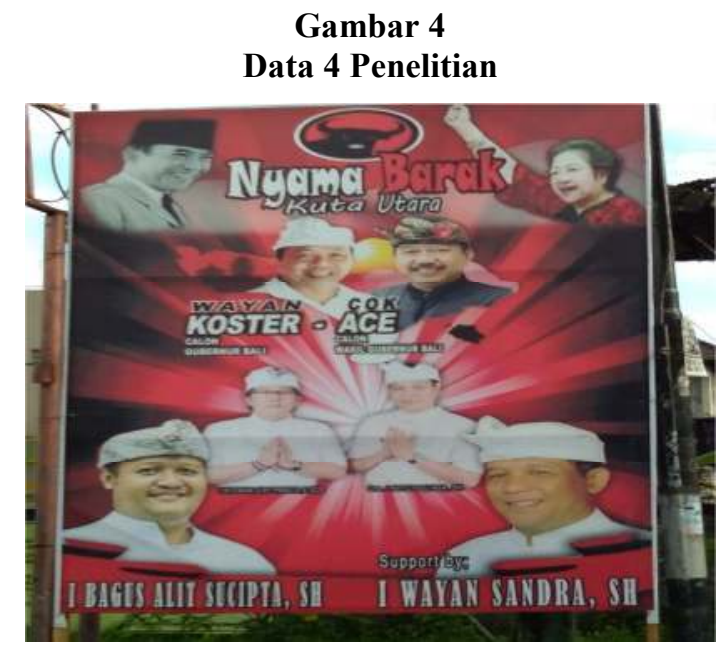

Pada data 4, tanda verbal yang ditampilkan dalam iklan politik tersebut tampak pada frasa "Nyama Barak Kuta Utara". Frasa tersebut terdiri atas dua kata yang menggunakan BB yaitu nyama 'saudara; teman' dan barak 'merah', sedangkan "Kuta Utara" merupakan nama wilayah (kecamatan di Kabupaten Badung). Tanda verbal tersebut dapat dimaknai bahwa pasangan calon, Koster Ace, yang ditampilkan dalam iklan didukung oleh saudara (masyarakat) yang ada di sebuah kecamatan yang mayoritas mengusung salah satu partai berwarna merah, yaitu PDI Perjuangan. Warna merah dalam trimurti memiliki makna 'sumber dari segala sumber, berani, dan cinta'. Warna tersebut merupakan lambang dari Dewa Brahma.

Tanda nonverbal yang tampak pada data 4 adalah lambang partai politik yang mengusung pasangan calon gubernur dan wakil gubernur tersebut. Simbol tersebut merupakan lambang identitas partai yaitu PDI Perjuangan dengan warna partai dominan merah seperti warna dasar iklan. Warna merah memiliki makna konotasi keberanian, kekuatan, energi, dan semangat.

Selain simbol partai politik, tampak juga gambar Ir. Soekarno yang merupakan presiden pertama Republik Indonesia dan gambar Ketua Umum PDI Perjuangan, Megawati Soekarno Putri.
Di tengah-tengah iklan tampak ilustrasi pancaran sinar yang berwarna putih yang menampilkan dua orang tokoh yaitu Bupati dan Wakil Bupati Badung. Ilustrasi kedua tokoh yang ditampilkan pada iklan tersebut memiliki makna bahwa kedua tokoh tersebut saat itu sedang bersinar sebagai pasangan kepala daerah di Kabupaten Badung yang memiliki program kerja yang berpihak kepada masyarakatnya.

Iklan politik yang tampak pada data di atas dapat dimaknai, baik secara verbal maupun nonverbal, bahwa pasangan calon gubernur dan wakil gubernur tersebut mendapat dukungan penuh masyarakat dan partai politik yang identik dengan warna merah, memiliki semangat dan kekuatan, untuk memenangkan pasangan calon tersebut.

Selain iklan politik persuasif pada Pilkada Bali 2018 dibuat oleh kedua pasangan calon dan pendukungnya, ada juga iklan politik yang dibuat oleh lembaga pemerintah (kepolisian) seperti pada data berikut ini.

\section{Gambar 5}

Data 5 Penelitian

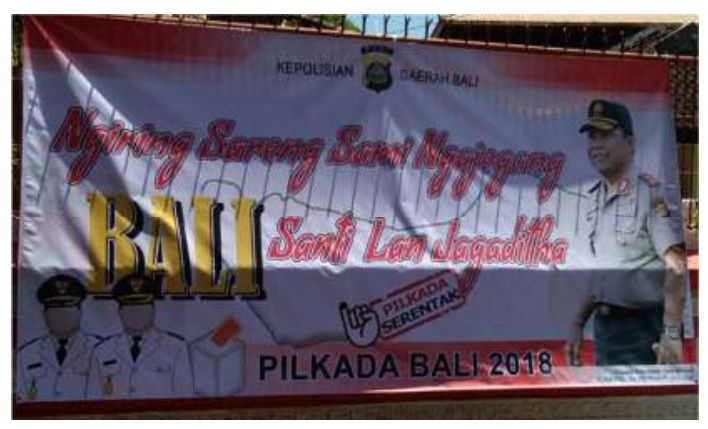

Tanda verbal yang digunakan oleh penulis iklan pada gambar 5 tampak menggunakan BB, BS, dan BI. Ketiga bahasa tersebut ditampilkan dalam sebuah kalimat "Ngiring Sareng Sami Ngajegang Bali Santi Lan Jagaditha". Kalimat tersebut menggunakan BB, ngiring sareng sami ngajegang Bali, yang diartikan dalam BI, ngiring 'ayo, mari'; sareng 'ikut, turut, bersama'; sami 'semua'; ngajegang 'tegak, kukuh'; dan 
Bali 'nama provinsi'. Sementara itu, kata santi lan jagaditha merupakan BS yang berarti 'damai dan sejahtera'. Kalimat tersebut secara literal memiliki arti 'mari semua bersama-sama menegakkan Bali yang damai dan sejahtera'.

Sementara itu, tanda verbal yang ada pada iklan tersebut merupakan imbauan dari lembaga kepolisian berupa kalimat imperatif yang mengajak seluruh masyarakat Bali untuk menjaga Bali agar tetap damai, aman dan sejahtera pada Pilkada Bali 2018. Secara verbal kalimat tersebut sebagai penanda bahwa Kapolda Bali yang tampak pada gambar pun ingin melestarikan budaya Bali dengan menampilkan kearifan lokal yaitu dengan menggunakan BB dan BS.

Penanda nonverbal yang ditampilkan pada data tersebut adalah logo lembaga kepolisian, sosok Kapolda Bali, ilustrasi pasangan calon pemerintah daerah tanpa nama, dan kotak suara. Penanda tersebut bermakna bahwa lembaga kepolisian ingin menunjukkan netralitasnya, yang tidak mendukung salah satu pasangan calon, dan mengimbau kepada seluruh masyarakat Bali untuk menggunakan hak pilihnya dalam Pilkada Bali 2018. Kapolda Bali juga mengajak masyarakat untuk memilih Gubernur dan Wakil Gubernur Bali dengan tetap menjaga kedamaian dan keamanan Bali pada saat pilkada serentak. Ilustrasi yang mengacungkan jari kelingking dan kotak suara merupakan gambaran sebuah ajakan kepada seluruh rakyat Bali untuk melakukan hak pilihnya dalam Pilkada Bali 2018 dengan tetap menjaga kedamaian dan keamanan menuju kesejahteraan masyarakat Bali.

\section{PENUTUP}

Iklan politik dalam Pilkada Bali 2018 menampilkan makna-makna yang terkandung dalam setiap komunikasi dan dapat diinterpretasikan secara jelas, baik yang berupa bahasa verbal maupun nonverbal. Pesan yang ditampilkan pada iklan politik pada Pilkada Bali 2018 memiliki makna yang hampir sama, yaitu menonjolkan sosiokultural dan sosioreligius dalam wujud kearifan lokal budaya masyarakat Bali pada umumnya.

Hingga saat ini, bahasa Bali dalam perkembangannya banyak menerima pengaruh dari BJK dan BS yang memiliki kekuatan religius dan menjadi jati diri masyarakat Hindu. Dalam tanda verbal, tampak digunakan pada iklan politik saat itu, selain aksara Bali dan BI. Penggunaan bahasa campuran tersebut menandakan bahwa penulis iklan ingin tetap menjaga dan melestarikan sastra dan budaya Bali yang tanpa mengesampingkan bahasa negara.

Tanda nonverbal yang ditampilkan pada iklan-iklan tersebut mengandung budaya mitos yang merupakan kepercayaan masyarakat Bali yang mayoritas umat Hindu. Selain itu, juga ditampilkan objek 'apa' dan 'siapa' berupa ilustrasi para tokoh (pahlawan nasional), dan logo partai politik pendukung pasangan calon. Umumnya, bentuk-bentuk iklan politik tersebut dapat dikenali dengan baik oleh masyarakat.

\section{DAFTAR PUSTAKA}

Alwi, H. (1998). Tata Bahasa Baku Bahasa Indonesia Edisi Ketiga. Jakarta: Balai Pustaka. 
Asrofah. (2014). Semiotik mitos Roland Barthes dalam analisis iklan di media massa. Jurnal Sasindo, 2(1), 1-14.

Bandana, S. I. W. G. (2012). Bahasa Jawa Kuna dan Sansekerta dalam wacana pembakaran dan penguburan jenazah: Kajian struktur dan makna. Dalam Sastra Jawa Kuna: Refleksi dulu, kini, dan tantangan ke depan (hlm. 177-187). Denpasar: Cakra Press.

Erawati, R. N. K. (2012). Parikan Bubuksah Gagangaking: Bahasa Jawa Kuna (BJK) dalam karya sastra Bali klasik. Dalam Sastra Jawa Kuna: Refleksi Dulu, Kini, dan Tantangan ke Depan (hlm. 119-139). Denpasar: Cakra Press.

Handono, S. (2017). Implikatur kampanye politik dalam kain rentang di ruang publik. Jurnal Aksara, 29(2), 253-266.

Mahsun. (2005). Metode penelitian bahasa: Tahapan strategi, metode, dan tekniknya. Jakarta: Rajawali Press.
Patton, M. Q. (2009). Metode evaluasi kualitatif. Yogyakarta: Pustaka Pelajar.

Pratiwi, Putri Satya. 2017. "Makna Tanda Verbal dan Nonverbal pada iklan "Wafer Tango". Sphota: Jurnal Linguistik dan Sastra, 6(1), 29-36. Diperoleh dari http://sphota.stibasaraswati.ac.id/ index.php/sphota/article/view/64.

Sobur, Alex. (2009). Semiotika komunikasi. Bandung: Remaja Rosdakarya.

Sudaryanto. (2015). Metode dan aneka teknik analisis bahasa. Yogyakarta: Sanata Dharma Univeristy Press.

Zakiyah, N. (2015). Implikatur dalam wacana kampanye politik pilkada calon gubernur dan calon wakil gubernur Lampung periode 20142019 (Tinjauan Pragmatik). Jurnal TAPIS, 11(1), 20-33. 